\title{
Renal Response to Acid Load after Phenformin
}

\author{
GÖSTA ROOTH, ULF BANDMAN
}

\section{CHEMICAL METHODS}

Urinary $\mathrm{pH}$, total acid elimination, and ammonium production was measured with the Radiometer titrator TTT 1 and the automatic ABU 12. The analytical procedure was done as described by Kildeberg (1968). Lactate was measured with the enzymatic method of Boehringer, and 3-hydroxybutyrate according to Williamson et al. (1962). ammonia production. In six patients with adult-type diabetes this response was reduced by a mean $50 \%$ after a therapeutic dose of phenformin. The reduced ability to compensate for acid loads may be one factor leading to metabolic acidosis and lactoacidosis sometimes associated with phenformin therapy.

\section{Introduction}

Lactic acidosis, usually fatal, may occur in diabetics on phenformin (Tranquada et al., 1963, Bengtsson et al., 1972; Varma et al., 1972). The blood lactate concentration in patients treated with phenformin is generally normal, or in some studies slightly raised, but the mechanism for the development of lactic acidosis is unknown. Though phenformin has been in use for years there is no agreement yet on its mode of action. Gordon and de Hartog (1973) showed that the oxidative phosphorylation and the adenosine triphosphate production in the renal cortex of rats was depressed by the drug. Aber et al. (1966), Alleyne and Scullard (1969), and Alleyne et al. (1971) showed a reduction of the renal glyconeogenesis and of the renal ammonium production to an acid load in rats.

The present study aimed to see whether human renal ammonium response to an acid load was reduced by phenformin, as such a reduction could initiate a metabolic acidosis which might develop into lactic acidosis.

\section{Patients and Methods}

Six patients with diabetes of adult type and without diabetic complications were investigated. Renal function as measured by serum creatinine was normal. Five of them were taking $50 \mathrm{mg}$ phenformin daily and one took $100 \mathrm{mg}$.

The "short" test described by Wrong and Davies (1959) was used. After a control collection of urine over two hours the patient was given ammonium chloride $0 \cdot 1 \mathrm{~g} / \mathrm{kg}$ body weight by mouth at about 10 a.m. To avoid gastric irritation this amount was given over one hour ir gelatin capsules of $0.25 \mathrm{~g}$ together with 11. water. Venous blood was taken before and three hours after the administration of ammonium chloride. Base excess was measured on both blood samples to ensure that the patients had taken their ammonium chloride. A second two-hour urine sample was voided at 5 p.m.

The test was performed twice on each patient-that is, during phenformin therapy and when they were on their diabetic diet only; in both cases after they had been treated for at least five days.

\footnotetext{
$\overline{\text { Department of Internal Medicine A, University Hospital, Lund, }}$ Sweden

GÖSTA ROOTH, M.D., Professor (Present address: Perinatal Research Unit, University Hospital, S-750 14 Uppsala, Sweden) ULF BANDMAN, M.D., Registrar
}

\section{Results}

All patients had an increase in their net acid elimination after the ammonium chloride test, due to a rise in their ammonia production (see table). The increase in the renal ammonia production was consistently lower during phenformin therapy than when the patients were on diet only. The response of two of the patients when on phenformin to the acid load as measured by the urinary ammonium elimination per hour was only $20 \%$ of that seen when the drug was not given.

Both the lactate and the 3-hydroxybutyrate concentration remained normal in the patients when on a diet only and when given additional phenformin. There was no increase in base deficit when they were on phenformin.

\begin{tabular}{|c|c|c|c|c|}
\hline \multirow{2}{*}{ Case No } & \multirow{2}{*}{ Age } & \multicolumn{2}{|c|}{ Increase of $\mathrm{NH} t$ in Urine after $\mathrm{NH}_{4} \mathrm{Cl}$ Test } & \multirow{2}{*}{$\begin{array}{l}\text { Percentage } \\
\text { Decrease } \\
\text { in Response }\end{array}$} \\
\hline & & $\begin{array}{c}\text { On Diet } \\
(\mathrm{mEq} / \mathrm{hr})\end{array}$ & $+\underset{(\mathrm{mEq} / \mathrm{hr})}{\text { Phenformin }}$ & \\
\hline $\begin{array}{l}1 \\
2 \\
3 \\
4 \\
5 \\
6\end{array}$ & $\begin{array}{l}42 \\
63 \\
69 \\
45 \\
59 \\
53\end{array}$ & $\begin{array}{l}1.72 \\
1.19 \\
1.23 \\
2.59 \\
1.67 \\
2.84\end{array}$ & $\begin{array}{l}1.10 \\
0.85 \\
0.24 \\
2.24 \\
0.32 \\
1.12\end{array}$ & $\begin{array}{l}36 \\
28 \\
80 \\
14 \\
81 \\
61\end{array}$ \\
\hline \multicolumn{3}{|c|}{ Mean percentage decrease ... } & . & 50 \\
\hline
\end{tabular}

The decrease in response to the acid load after phenformin is significan

\section{Discussion}

It is well known that the plasma level of glucose is lowered by phenformin in diabetic patients, though the mechanism or mechanisms behind this effect is still controversial. The three main theories favour an enhanced peripheral glucose utilization, a decreased glucose absorption, and an inhibition of gluconeogenesis (Searle et al., 1966; Alleyne and Scullard, 1969; Alleyne et al., 1971; Gordon and de Hartog, 1973). The decrease in kidney gluconeogenesis is intimately related to the ammonia production, at least in rats. Should this also hold true for man the present study would support the opinion that phenformin in normal therapeutic dose reduces glyconeogenesis in the kidney.

Of greater theoretical importance could be the finding that the renal response to an intense acid load may be depressed by about $50 \%$ by a normal therapeutic dose of phenformin. Provided the creatinine level is normal, the kidneys will still be able to cope with the daily acid load.

Higher concentrations of phenformin are likely to depress renal function more, as indicated by studies in rats by Alleyne and his co-workers. Moreover, phenformin is eliminated via the kidneys and this elimination is reduced and the plasma $(\mathrm{P}<0.01, t=4.35, \mathrm{n}=6)$ 
phenformin concentration correspondingly increased in patients with plasma creatinine levels of 2 to $3 \mathrm{mg} / 100 \mathrm{ml}$ or more (Tranquada et al., 1963). Thus renal damage could trigger a vicious circle and lead to a gradually developing metabolic acidosis. The lactic acidosis discussed in connexion with reduced renal function could then be the end stage. Unfortunately, little information is available about the early metabolic acidosis in cases that develop lactic acidosis.

\section{References}

Aber, S. M., Morris, L. O., and Hously, E. (1966). Nature, 212, 1589.
Alleyne, G. A. O., Besterman, H. S., and Flores, H. (1971). Clinical Science, $40,107$.

Alleyne, G. A. O., and Scullard, G. H. (1969). Fournal of Clinical Investigation, 48, 364 .

Bengtsson, K., Karlberg, B., and Lindgren, S. (1972). Acta Medica Scandinavica, 191, 203

Gordon, E. E., and de Hartog, M. (1973). Diabetes, 22, 50.

Kildeberg, P. (1968). |Clinical Acid-base Physiology. Copenhagen, Munksgaard. Searle, G. L., et al. (1966). Diabetes, 15, 173

Tranquada, R. E., Bernstein, S., and Martin, H. E. (1963). Fournal of the American Medical Association, 184, 37.

Varma, S. K., Heaney, S. J., Whyte, W. C., and Walker, R. S. (1972). British Medical fournal, i, $20 \overline{5}$.

Williamson, D. H., Mellanby, J., and Krebs, H. A. (1962). Biochemical Fournal, 82, 90.

Wrong, O., and Davies, H. E. F. (1959). Quarterly fournal of Medicine, 28, 259.

\title{
Different Effects of Adrenergic Beta-receptor Blockade on Heart Rate Response to Mental Stress, Catecholamines, and Exercise
}

\author{
S. H. TAYLOR, M. K. MEERAN
}

British Medical fournal, 1973, 4, 257-259

\section{Subjects and Method}

Studies were made on six normal men, aged 26-47 years. None had any symptoms of systemic disease, none were obese, and in all the blood pressure was within normal limits. Two subjects were the authors; the remainder were professional colleagues who fully understood the aims and nature of the investigation.

The magnitude and duration of effect of a single $40-\mathrm{mg}$ oral tablet of oxprenolol on the tachycardias associated with motor-car driving, isoprenaline infusion, and walking were compared against placebo in six normal people by a double-blind study. The tachycardias due to driving and isoprenaline were both conspicuousy reduced for over eight hours; the magnitude and duration of the reduction in exercise tachycardia was substantially less. Thus relatively small doses of beta-receptor antagonists will suppress the increase in heart rate induced by mental stress or catecholamines with relatively little effect on the response to everyday exercise. Possibly smaller doses of these drugs would relieve emotionallyinduced anginal pain and tachycardia.

\section{Introduction}

Emotional stress, catecholamines, and physical exertion all induce an increase in heart rate. During recent studies of the effects of environmentally-induced psychological stress on the heart it was noticed that small doses of the beta-receptor antagonist oxprenolol had conspicuously greater effect on the tachycardia associated with mental stress than on the heart rate increase during walking. In view of the possible therapeutic implications of this observation the following study was designed to define more closely the quantitative relation between the tachycardias due to these three stimuli in terms of their inhibition by beta-receptor antagonists.

\footnotetext{
Cardiovascular Unit, University Department of Medicine, The General Infirmary, Leeds LS1 3EX

S. H. TAYLOR, M.B., F.R.C.P., Senior Lecturer in Medicine, Consultant Physician, and Deputy Director, Cardiovascular Unit

M. K. MEERAN, M.R.C.P., F.C.P.(S.A.), Senior Ciha Research Fellow and Honorary Lecturer in Medicine
}

\section{DESIGN OF STUDY}

The heart rate was measured from an electrocardiographic record in each subject in the following three situations. (1) Driving a motor-car for 15-20 minutes in heavy city traffic. (2) In the supine position during a two-minute intravenous isoprenaline infusion sufficient to raise the heart rate to the levels observed during driving. (3) During treadmill walking of two minutes' duration sufficient to raise the heart rate to similar levels.

Preliminary studies were carried out to familiarize each subject with the programme of investigation and determine the peak heart rate response regularly achieved by motor-car driving.in city traffic; the dose of intravenous isoprenaline and level of treadmill walking necessary to give similar heart rate increases were then determined. Motor-car driving carried out over a random route through Leeds city centre for 15-20 minutes repeatedly resulted in peak heart rate increments of 30 beats/min or more in all subjects. A similar increase in heart rate was induced by treadmill walking at 3 m.p.h. ( 5 k.p.h.) on a $10-15^{\circ}$ incline for two minutes.

The definitive double-blind studies were begun at 8.00 a.m., two hours after a light breakfast and one hour after a single oral tablet of $40 \mathrm{mg}$ oxprenolol or a matched placebo tablet of sucrose and starch. A control electrocardiogram was recorded with each subject sitting quietly at the wheel of his car. A 15-20 minute period of city driving was then undertaken on a random route selected by the monitoring observer travelling as a passenger. The subject then returned to the laboratory and, after 10 minutes' rest, a two-minute intravenous infusion of isoprenaline was given in a dose that had been determined beforehand would raise the heart rate in that subject by about 30 beats $/ \mathrm{min}$. After a further 10 minutes' rest, by which time the heart rate had returned to preisoprenaline infusion levels in all subjects, the treadmill walking test was performed. Similar studies were 